\title{
Lack of expression of the chondroitin sulphate proteoglycan neuron-glial antigen 2 on candidate stem cell populations in paediatric acute myeloid leukaemia/abn(11q23) and acute lymphoblastic leukaemia/t(4;11)
}

\author{
J. Neudenberger, ${ }^{1}$ M. Hotfilder, ${ }^{1}$ A. \\ Rosemann, ${ }^{1}$ C. Langebrake, ${ }^{2} \mathrm{D}$. \\ Reinhardt, ${ }^{2}$ R. Pieters, ${ }^{3}$ A. Schrauder, ${ }^{4}$ \\ M. Schrappe, ${ }^{4}$ S. Röttgers, ${ }^{5}$ J. Harbott ${ }^{5}$ \\ and J. Vormoor ${ }^{1}$ \\ ${ }^{1}$ Department of Paediatric Haematology and \\ Oncology, University Children's Hospital \\ Muenster, Muenster, ${ }^{2}$ AML-BFM Study Centre, \\ University of Hannover, Hannover, Germany, \\ ${ }^{3}$ Erasmus MC-Sophia Children's Hospital, \\ University Medical Centre, Rotterdam, The \\ Netherlands, ${ }^{4} A L L-B F M$ Study Centre, University \\ of Kiel, Kiel, and ${ }^{5}$ Department of Paediatric \\ Haematology and Oncology, University Children's \\ Hospital Giessen, Giessen, Germany
}

Received 13 November 2005; accepted for publication 10 January 2006

Correspondence: Dr Josef Vormoor, Northern Institute for Cancer Research, Paul O'Gorman Building, Medical School, University of Newcastle Upon Tyne, Framlington Place, Newcastle Upon Tyne NE2 4HH, UK. E-mail: h.j.vormoor@ncl.ac.uk

\begin{abstract}
Summary
It has increasingly been acknowledged that only a few leukaemic cells possess the capability to renew themselves and that only these self-renewing leukaemic stem cells are able to initiate relapses. Therefore, these leukaemic stem cells should be the target cells for therapy and for minimal residual disease (MRD) detection. Because of its presence on blasts of 11q23rearranged high-risk leukaemic patients, neuron-glial antigen 2 (NG2) is thought to be a valuable marker for detecting leukaemic stem cells. Six acute myeloid leukaemia (AML)/abn(11q23) and three acute lymphoblastic leukaemia (ALL)/t $(4 ; 11)$ samples were analysed by four-colour flow cytometry for NG2 expression on primitive cell populations. Candidate leukaemic cell populations were defined by the antigen profiles $\mathrm{CD} 34^{+} \mathrm{CD} 38^{-}$ in AML and $\mathrm{CD} 34^{+} \mathrm{CD} 19^{-} \mathrm{CD} 117^{+}$in ALL. Surprisingly, in all patients these candidate stem cell populations were shown to lack expression of NG2. Instead, a correlation between the expression of the myeloid differentiation marker CD33 and increasing levels of NG2 on maturing cells could be demonstrated. Similarly, in ALL patients $\mathrm{CD} 34^{+} \mathrm{CD} 19^{+}$cells showed a higher expression of NG2 mRNA compared with $\mathrm{CD} 34^{+} \mathrm{CD} 19^{-}$. Thus, NG2 appears to be upregulated with differentiation and not to be expressed on primitive disease-maintaining cells. This hampers the clinical use of NG2 as a therapeutic target and as a sensitive marker for MRD detection.
\end{abstract}

Keywords: leukaemic stem cell, neuron-glial antigen 2, 11q23, acute lymphoblastic leukaemia, acute myeloid leukaemia.
Increasing evidence suggests that, similar to normal haematopoiesis, acute leukaemic patients are maintained by a small subpopulation of highly specialised malignant stem cells (McCulloch, 1983; Griffin \& Löwenberg, 1986; Lapidot et al, 1994; Bonnet \& Dick, 1997). Differences between normal and leukaemic stem cells with regard to survival pathways, proliferation signals, regulation of apoptosis and interaction with the bone marrow microenvironment constitute potential therapeutic targets. Due to the similarities between normal and leukaemic haematopoietic stem cells, it has been impossible to purify leukaemic stem cells to high purity. Purification of leukaemic stem cells is, however, a prerequisite for studying their biology and to understand the differences between normal and leukaemic stem cells. Thus, it is of the utmost importance to identify markers specific for leukaemic stem cells.

First described on rat oligodendrocyte progenitor cells (Stallcup \& Cohn, 1976), the chondroitin sulphate proteoglycan neuron-glial antigen 2 (NG2) molecule and its human homologue is known to be expressed in the vascular system, skeletal and cardial myoblasts, chondroblasts and different human tumours as well. Its physiological function has still not been completely understood, but recent evidence indicates that NG2 is involved in signalling pathways that regulate the proliferation and migration of precursor cells (Levine \& Nishiyama, 1996). While NG2 cannot be detected on the 
surface of normal haematopoietic precursor cells, the monoclonal antibody $7 \cdot 1($ moAb $7 \cdot 1)$ recognises the $220-240 \mathrm{kDa}$ chondroitin sulphate proteoglycan NG2 on 11q23/mixed lineage leukaemia (MLL)-rearranged leukaemic blasts (Smith et al, 1996). Although NG2 seems to promote the metastatic potential of melanoma cells (Burg et al, 1998), a biological function of NG2 in leukaemic patients with 11q23/MLL rearrangements has yet to be identified.

Throughout the past years, NG2 has been incorporated in diagnostic panels for immunophenotyping of leukaemic patients because of its positive predictive value for $M L L$ rearrangements in childhood and adult acute myeloid leukaemia (AML) and acute lymphoblastic leukaemia (ALL). In addition, NG2 expression has been evaluated concerning the detection of persisting minimal residual disease (MRD) (Behm et al, 1996; Smith et al, 1996; Hilden et al, 1997; Wuchter et al, 2000; Borkhardt et al, 2002; Schwartz et al, 2003).

Based on the specificity of NG2 expression on haematopoietic cells for 11q23/MLL-rearranged leukaemic patients, we report here our efforts to evaluate NG2 expression as a marker for leukaemic stem cells.

\section{Materials and methods}

\section{Patients and cell samples}

We examined bone marrow or peripheral blood samples from 11 paediatric patients [eight AML: unique patient numbers (UPNs) 01-08; 3 ALL: UPN 1-2, 10] with 11q23/MLL gene rearranged leukaemia by flow cytometry. Two of the 11 patients (UPN 07, 08) were excluded, because they tested negative for NG2. Of the remaining nine patients, two patients were treated at the Department of Paediatric Haematology and Oncology, University of Münster. Six samples were provided by the Berlin-Frankfurt-Münster AML (AML-BFM) MRD study group, and one by the Erasmus MC-Sophia Children's Hospital. All samples were obtained at the time of diagnosis after informed consent from the guardians and stored in liquid nitrogen. The ethics committee of the Medical Faculty, University of Münster, approved the investigation. Four of six AML patients were positive for the translocation $\mathrm{t}(9 ; 11)(\mathrm{p} 22 ; \mathrm{p} 23)$, one had a translocation $\mathrm{t}(10 ; 11)$. In one patient the $M L L$ translocation partner could not be identified $(t(? ; 11))$, but an 11q23 rearrangement was revealed by fluorescence in situ hybridisation (FISH). All ALL patients had a translocation $\mathrm{t}(4 ; 11)$ in the leukaemic clone. Two of the ALL samples (UPN 1,2) were also available for RNA-based analyses.

From additional four ALL/t $(4 ; 11)$ samples, only RNA samples for molecular analysis were available (provided by the ALL-BFM study group) (UPN 3-5, 9). The ALL patient numbers match the UPN used by Hotfilder et al (2005) and are identical samples.

Cell lines HeLa, K562 and MV4;11 were used as negative and positive controls, respectively, for the subsequent investigations.

\section{Flow cytometry}

The AML samples were stained at saturating concentrations with: anti-NG2 (moAb 7·1) - phycoerythrin (PE), anti-CD34allophycocyanin (APC), anti-CD33-PE-cyanin-5·1 (PECy5) and anti-CD38-fluorescein isothiocyanate (FITC) antibodies. The ALL samples were stained with the following antibody panel: anti-NG2-PE, anti-CD34-APC, anti-CD19-FITC and anti-CD117-PECy5 (isotype control for all antibodies: mouse immunoglobulin (Ig) $\mathrm{G}_{1}$; all antibodies from Immunotech, Beckman Coulter, Marseille, France). In each patient, $5 \times 10^{6}$ cells were incubated with the specific antibody panel and another $5 \times 10^{6}$ cells were incubated with mouse IgG isotype-control antibodies. After having been stained with the antibodies at room temperature for $20 \mathrm{~min}$, the samples were incubated with BD lysis for $5 \mathrm{~min}$. Subsequently, the samples were washed twice with phosphate-buffered saline (PBS), centrifuged at $260 \mathrm{~g}, 5 \mathrm{~min}, 21^{\circ} \mathrm{C}$, and resuspended in PBS.

Time delay calibration was accomplished prior to each measurement using APC beads following the manufacturer's instructions. Calibration and compensation were achieved by analysing unstained and single-stained anti-CD38-FITC, antiCD33-APC, anti-CD33-PE and anti-CD33-PECy5 of AML and single-stained anti-CD19-PE, anti-CD19-FITC, anti-CD19APC and anti-CD19-PECy5 cells of ALL samples.

Flow cytometry measurements were performed according to the published protocols (Vormoor et al, 1998; Baersch et al, 1999). Detection of NG2 and immunophenotypic analyses were carried out on a FACSCalibur, by using the CELL QUEST PRo and PAINT-A-Gate software [Becton Dickinson (BD), Heidelberg, Germany]. After calibration and compensation as described above, 10000 events were acquired of both the specific- and the isotype-stained cells. Subsequently, a storage gate was set on the $\mathrm{CD} 34^{+} \mathrm{CD} 38^{-}$events for AML or on the $\mathrm{CD} 34^{+} \mathrm{CD} 19^{-}$events for ALL samples. Another $1 \times 10^{6}$ cells (ALL patient no. 10: $6 \times 10^{5}$ cells) of the same samples were acquired and only the gated events were stored. Between the single runs, the FACSCalibur was flushed with FACSRinse (BD) and distilled water, in order to avoid a carryover of cells from previous runs. The next run was not started until the number of events within the pure water-run was below 15 events in 1:30 min. In general, the acquisition speed was kept between 1000 and 2000 events/min.

\section{Sorting of cells for reverse-transcriptase polymerase chain reaction analysis and isolation of $R N A$}

Sorting and RNA-isolation strategies have previously been described (Hotfilder et al, 2002). From each population $\left(\mathrm{CD} 34^{+} \mathrm{CD} 19^{-}\right.$and $\left.\mathrm{CD} 34^{+} \mathrm{CD} 19^{+}\right)$a total of 1000 cells were sorted directly into $100 \mu \mathrm{l}$ of RLT buffer (supplied with the RNeasy-Mini-Kit; Qiagen, Hilden, Germany); after $250 \mu$ l of RLT buffer and $3.5 \mu$ of $\beta$-mercaptoethanol were added, the samples were passed through Qiashredder columns (Qiagen) according to the manufacturer's protocol. The lysate was 
frozen and stored at $-80^{\circ} \mathrm{C}$. According to the RNeasy-Mini-Kit (Qiagen) protocol, total RNA was extracted from frozen lysate. RNA was finally eluted with $30 \mu$ of ribonuclease-free water and stored at $-80^{\circ} \mathrm{C}$.

\section{Reverse-transcriptase polymerase chain reaction for NG2}

RNA-based methods were carried out by using a nested reversetranscriptase polymerase chain reaction (RT-PCR). For the first amplification round, the OneStep RT-PCR kit (Qiagen) was used. Five microlitres of total RNA was transcribed into complementary DNA and amplified. The reaction solution had a total volume of $50 \mu \mathrm{l}$ containing $0.2 \mu \mathrm{mol} / \mathrm{l}$ of each primer (sense: GAACTTCACTCAGGCAGAGGTC, antisense: CTGTG TGACCTGGAAGAGCA), $400 \mu \mathrm{mol} / \mathrm{l}$ of each deoxyribonucleoside triphosphate, 1x OneStep RT-buffer, and OneStep RTPCR enzyme mix. The RT reaction and amplification conditions were $30 \mathrm{~min}$ at $50^{\circ} \mathrm{C}, 15 \mathrm{~min}$ at $95^{\circ} \mathrm{C}$, followed by $35 \mathrm{PCR}$ cycles $\left(30 \mathrm{~s}\right.$ at $94^{\circ} \mathrm{C}, 30 \mathrm{~s}$ at $55^{\circ} \mathrm{C}, 45 \mathrm{~s}$ at $\left.72^{\circ} \mathrm{C}\right)$, terminated by an extension step of $10 \mathrm{~min}$ at $72^{\circ} \mathrm{C}$ and a final cooling down to $12^{\circ} \mathrm{C}$. A total of $20 \mu \mathrm{l}$ of each PCR reaction mixture was applied to $0.8 \%$ agarose gel stained with $0.5 \mu \mathrm{g} / \mathrm{ml}$ ethidium bromide and visualised under ultraviolet illumination. Finally, the expected and obtained 345-bp PCR products were isolated and sequenced in order to check the identity of the obtained amplification products (Cycle SeqKit; Applied Biosystems, Weiterstadt, Germany).

For semiquantification the second PCR was performed on the LightCycler instrument by using the LightCycler-DNAmaster-SYBR-green-I-kit (Roche, Mannheim, Germany). In accordance with the manufacturer's protocol the hot-start method was used (Taq-Start antibody; Clontech, Heidelberg, Germany). The second PCR reaction mix contained $2 \mu \mathrm{l}$ amplification product of the first PCR, $0 \cdot 2 \mu \mathrm{mol} / \mathrm{l}$ of each second nested primer (sense: AGAGACCTTTGTTCTTCCAGAGG, antisense: GGTCTACGCTGGGAATATTCTGT), $3 \mathrm{mmol} / \mathrm{l}$ of $\mathrm{MgCl}_{2}$ and $1 \mathrm{x}$ LightCycler-DNA-master-SYBRgreen buffer. Cycling conditions were set to $2 \mathrm{~min}$ at $95^{\circ} \mathrm{C}$, followed by $40 \mathrm{PCR}$ cycles $\left(1 \mathrm{~s}\right.$ at $94^{\circ} \mathrm{C}, 5 \mathrm{~s}$ at $55^{\circ} \mathrm{C}, 10 \mathrm{~s}$ at $72^{\circ} \mathrm{C}$ ). A standard curve was generated by RT-PCR analysis with dilutions of $10^{\circ}, 10^{-1}, 10^{-2}$ and $10^{-3}$ of RNA from the NG2-positive cell line HeLa and a semilogarithmic regression curve for relative quantification was calculated (regression curve equation: $x=\mathrm{e}^{2 \cdot 424-0 \cdot 35 y}$, where $x$ is relative NG2 RNA concentration and $y$ is obtained crossing point).

\section{Results}

\section{NG2 expression of the bulk leukaemic population}

In order to determine NG2 cell surface expression, diagnostic bone marrow or peripheral blood samples from 11 paediatric patients with $M L L$ gene-rearranged acute leukaemia were analysed by flow cytometry (Figs $1 \mathrm{~A}$ and $2 \mathrm{~A}$ ). The blasts of six AML and three ALL samples were positive for NG2 and constituted the sample collective of the following investigations.

Determination of NG2 expression on primitive leukaemic progenitor cell populations

In the next step, NG2 expression on immature $\mathrm{CD} 34^{+}$cell populations was analysed. Immature, non-lineage committed progenitor/stem cells were defined by a $\mathrm{CD} 34^{+} \mathrm{CD} 38^{-}$(in AML samples) or a $\mathrm{CD} 34^{+} \mathrm{CD} 19^{-}$immunophenotype (in ALL samples).

The leukaemic stem cell population in AML has been shown to be $\mathrm{CD}^{+} 4^{+} \mathrm{CD} 38^{-}$(Lapidot et al, 1994; Bonnet \& Dick, 1997; Blair et al, 1998; Bonnet, 2005). Cells with this CD $34^{+} \mathrm{CD} 38^{-}$ immunophenotype are rare in diagnostic bone marrow and peripheral blood samples, and the percentage varied between $0.02 \%$ and $0 \cdot 1 \%(n=6)$.

In order to analyse this rare cell population, $1 \times 10^{6}$ events were acquired and a storage gate was set for $\mathrm{CD} 34^{+} \mathrm{CD} 38^{-}$ events (see Materials and methods). Isotype controls and stringent washing procedures were applied to guarantee the specificity of the analysis. The gating strategies are displayed in Fig 1A. Histogram analysis showed that the $\mathrm{CD} 34^{+} \mathrm{CD} 38^{-}$cell population was completely negative ( $n=5$; UPNs $01-05)$ or had only a very low $(n=1$; UPN 06$)$ expression of NG2 (Fig $1 \mathrm{~A}$ and $\mathrm{B}$ ).

In $\mathrm{ALL} / \mathrm{t}(4 ; 11)$, primitive $\mathrm{CD} 34^{+} \mathrm{CD} 19^{-}$cells have been shown to be part of the leukaemic cell clone (Quijano et al, 1997; Hotfilder et al, 2005). CD $34^{+} \mathrm{CD} 19^{-}$cells in diagnostic samples are rare and in our study comprised only $0 \cdot 25-0 \cdot 6 \%$ of all cells $(n=3)$. Rare event analysis of this population was performed as described above. The gating strategies are displayed in Fig 2A. Similar to what has been found in previous studies (Baersch et al, 1999), the $\mathrm{CD} 19^{-}$population was heterogeneous. By the use of CD117 expression, a $\mathrm{CD} 34^{+} \mathrm{CD} 117^{+}$population that was 'truly' negative for CD19 expression (log-normal antigen distribution) could be separated from a $\mathrm{CD} 34^{+} \mathrm{CD} 117^{-}$population. The latter looked like the truncated low end of the $\mathrm{CD} 19^{+}$leukaemic bulk population. An overlap of populations is a significant problem in the analysis of rare populations against the background of a dominant population. In order to avoid this problem, $\mathrm{CD} 34^{+} \mathrm{CD} 19^{-} \mathrm{CD} 117^{-}$cells were excluded from the analysis. Similar to the AML samples, in all three ALL samples analysed, the most immature $\mathrm{CD} 34^{+} \mathrm{CD} 19^{-} \mathrm{CD} 117^{+}$cells did not express NG2 (Fig 2A and B).

In order to investigate whether NG2 expression is dependent on differentiation, NG2 expression was correlated with myeloid and lymphoid differentiation antigens.

\section{Correlation between NG2 expression and myeloid or lymphoid differentiation antigens}

Because of the stringent gating for $\mathrm{CD} 34^{+} \mathrm{CD} 38^{-}$events, in four of the six AML samples no $\mathrm{CD} 34^{+} \mathrm{CD} 33^{+}$-positive cells 
B

A
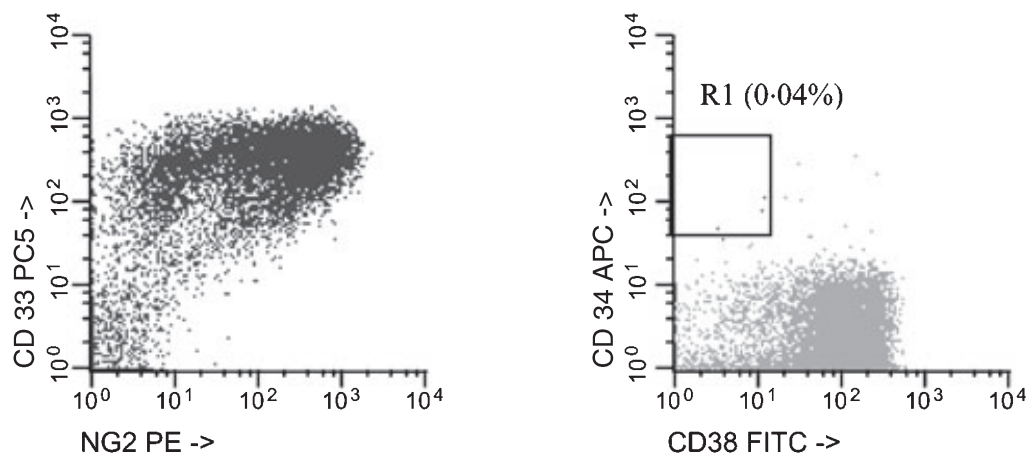

$\underline{\mathrm{R} 1}$

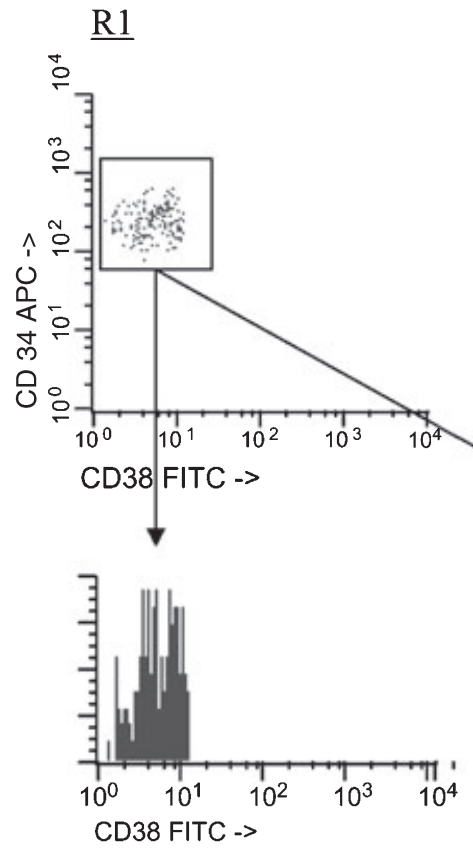

$\underline{\text { Patient }}$ CD34 ${ }^{+}$CD38-

\#01

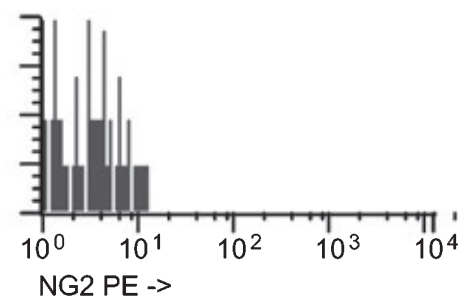

\#02

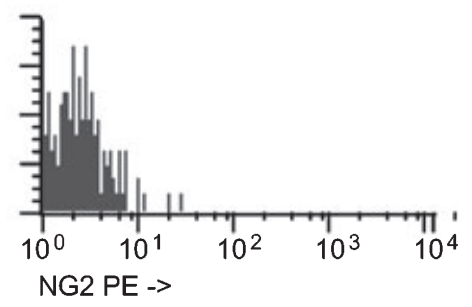

\#03

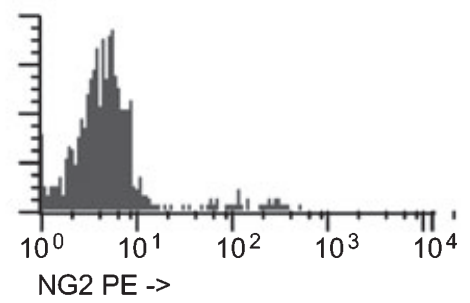

\#04

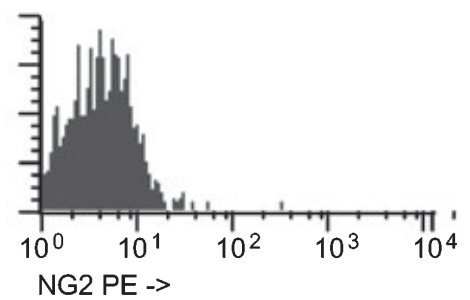

\#05

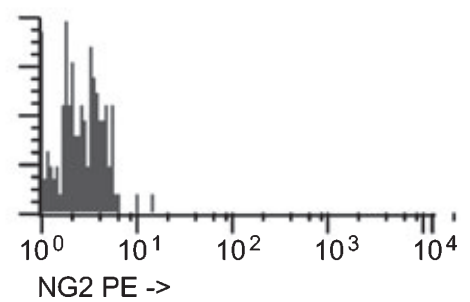

\#06

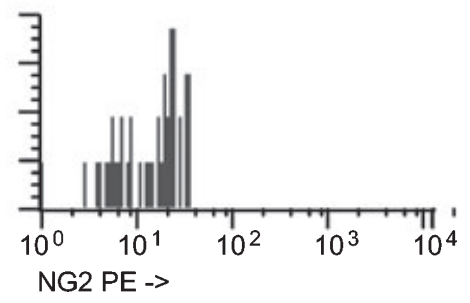

Fig 1. (A) Flow cytometric analysis of the neuron-glial antigen 2 (NG2) expression on $\mathrm{CD} 34^{+} \mathrm{CD} 38^{-}$acute myeloid leukaemia (AML) cells in unique patient number (UPN) 02. Upper left quadrant: the bulk leukaemic population is NG2-positive. Upper right and middle left quadrant: definition of the rare event gate. Middle right quadrant: forward and side scatter profile of the population. Histograms underline the lack of CD38 and the lack of NG2 of the gated events $\left(\mathrm{R}_{1}\right)$. (B) Flow cytometric analysis of the NG2 expression on CD34 ${ }^{+} \mathrm{CD} 38^{-}$AML cells in UPN $01-06$. 

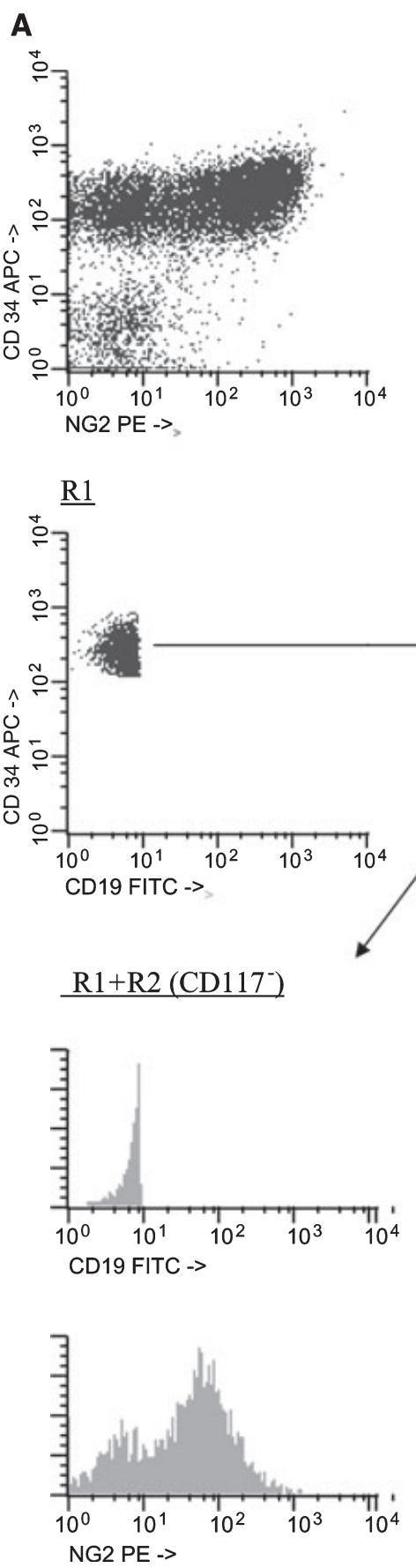

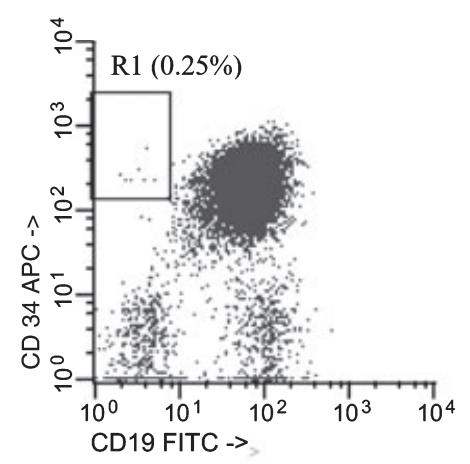

B
Patient

$\underline{\mathrm{R} 1}$

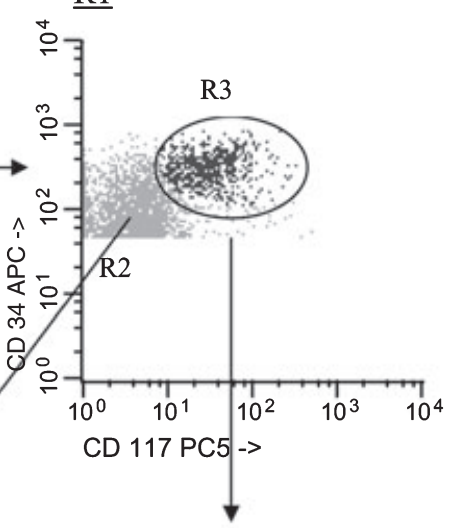

$\underline{\mathrm{R} 1+\mathrm{R} 3\left(\mathrm{CD} 117^{+}\right)}$
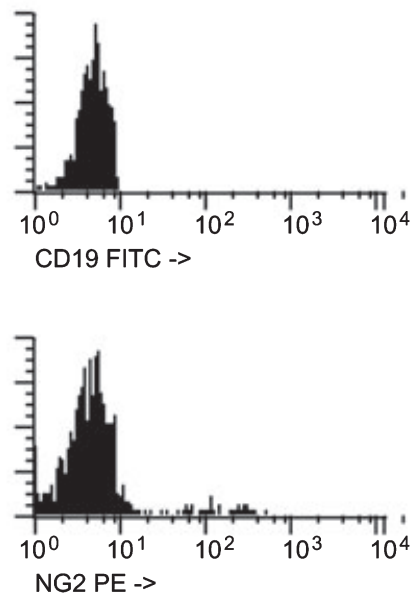

\#1

$\mathrm{CD}^{+} 4^{+} \mathrm{CD} 19^{-} \mathrm{CD} 117^{+}$

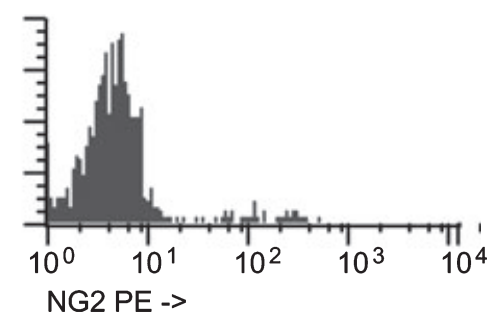

\#2

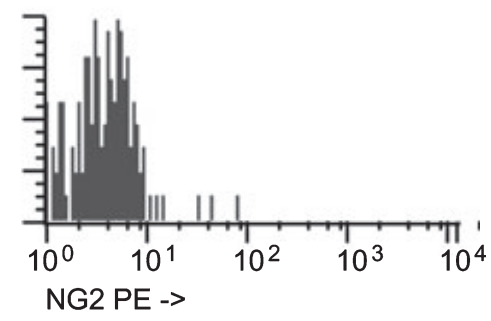

$\# 10$

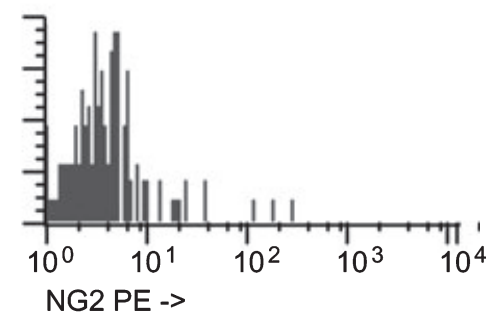

Fig 2. (A) Flow cytometric analysis of the neuron-glial antigen 2 (NG2) expression on CD $34^{+} \mathrm{CD} 19^{-} \mathrm{CD} 117^{+}$acute lymphoblastic leukaemia (ALL) cells in unique patient numbers (UPN) 1. Upper left quadrant: the bulk leukaemic population is NG2-positive. Upper right and second row left quadrant: definition of the rare event gate. Second row right quadrant: Within the rare event analysis gate $\left(\mathrm{R}_{1}\right)$ the distinct $\mathrm{CD} 117^{+}$population is marked black and was analysed more closely for antibody expression. Whereas the black CD19- cells present the log-normal autofluorescence profile $\left(R_{1}+R_{3}\right)$, grey events of the same population are only the truncated lower end of the overlap of a log-normal CD19 $9^{+}$cell population $\left(R_{1}+R_{2}\right)$, thus presenting false negative $\mathrm{CD}_{1} 9^{-}$cells. (B) Flow cytometric analysis of the NG2 expression on CD $34^{+} \mathrm{CD} 19^{-} \mathrm{CD} 117^{+}$ALL cells in UPN 1,2 and 10.

could be detected inside the storage gate. However, in two patients a correlation of expression of CD33 with NG2 could be shown by flow cytometry (Fig 3), which indicated that NG2 was upregulated in AML/abn(11q23) with increasing myeloid differentiation.
As previously published, $12 \mathrm{ALL} / \mathrm{t}(4 ; 11)$ samples were analysed by FISH, and the immature $\mathrm{CD} 34^{+} \mathrm{CD} 19^{-}$population was revealed to carry the translocation in $32 \cdot 0-92 \cdot 8 \%$ of the cells (Hotfilder et al, 2005). In six of these 12 ALL samples, spare RNA was available from sorted $\mathrm{CD} 34^{+} \mathrm{CD} 19^{+}$and 

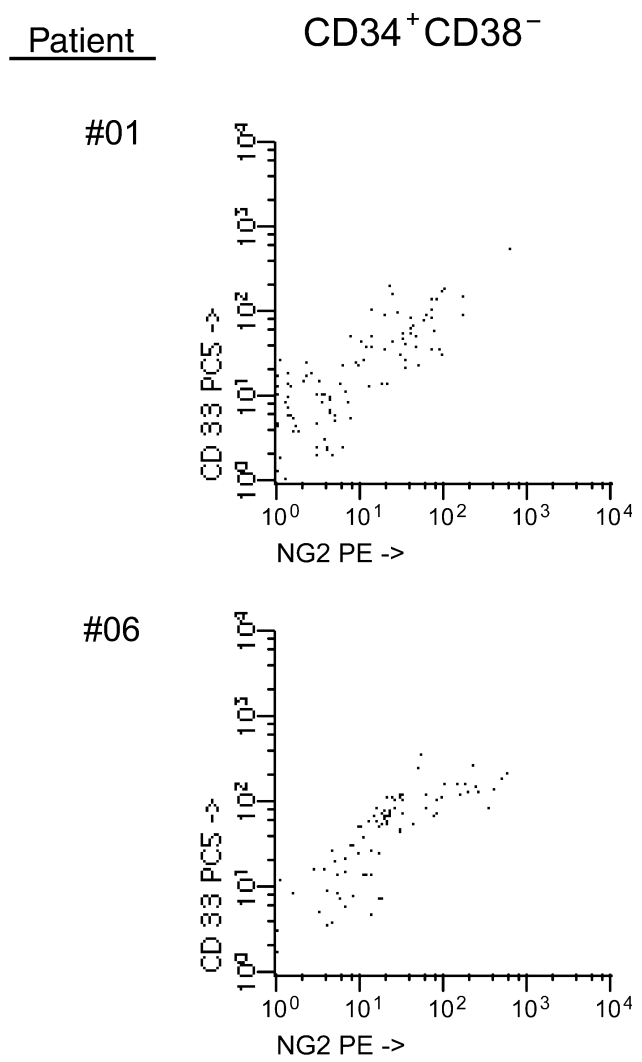

Fig 3. Correlation of the myeloid differentiation marker CD33 and the expression of neuron-glial antigen 2 in acute myeloid leukaemia unique patient numbers 01 and 06 .

$\mathrm{CD} 34^{+} \mathrm{CD} 19^{-}$cells for RT-PCR analysis of $N G 2$ expression. NG2 mRNA could be amplified in the $\mathrm{CD} 34^{+} \mathrm{CD} 19^{+}$compartment of all six patients. Compared with the $\mathrm{CD} 34^{+} \mathrm{CD} 19^{+}$ population, the level of amplification products in $\mathrm{CD} 34^{+} \mathrm{CD} 19^{-}$cells was always lower (Fig 4). Semiquantitative RT-PCR revealed a mean $2 \cdot 7$ (range: $1 \cdot 5-4 \cdot 454$ )-fold increase of NG2 expression in $\mathrm{CD} 34^{+} \mathrm{CD} 19^{+}$cells compared with $\mathrm{CD} 34^{+} \mathrm{CD} 19^{-}$cells, underlining the higher expression of NG2 in more mature cells (Table I).

\section{Discussion}

Neuron-glial antigen 2 expression has been shown to correlate with the presence of $M L L$ rearrangement in leukaemic patients (Hilden et al, 1997; Wuchter et al, 2000; Borkhardt et al, 2002; Schwartz et al, 2003). Accordingly, we detected NG2 expression by flow cytometry in nine of 11 patients $(82 \%)$ with AML or ALL and cytogenetic or molecular evidence of 11q23/MLL rearrangement. Despite the cell surface expression of NG2 on the leukaemic blasts in all nine patients, candidate leukaemic stem cells were shown to lack expression of NG2.

In AML, there is solid evidence that the immature $\mathrm{CD} 34^{+} \mathrm{CD} 38^{-}$cell compartment harbours the leukaemic stem cells (Lapidot et al, 1994; Bonnet \& Dick, 1997; Blair et al,
1998; Bonnet, 2005). Therefore, our results indicate that primitive $\mathrm{CD} 34^{+} \mathrm{CD} 38^{-}$leukaemic stem cells in $\mathrm{AML} /$ abn(11q23) do not express NG2. Otherwise, it should have been possible to identify a $\mathrm{NG}_{2}^{+} \mathrm{CD} 34^{+} \mathrm{CD} 38^{-}$subpopulation. Consistent with this observation, flow cytometric analysis revealed a correlation between the expression of the myeloid differentiation marker CD33 and increasing levels of NG2 on maturating AML blasts.

In $\mathrm{ALL} / \mathrm{t}(4 ; 11)$ the $\mathrm{CD} 34^{+} \mathrm{CD} 19^{-}$cell compartment is more heterogeneous. While it has been shown that $\mathrm{CD} 34^{+} \mathrm{CD} 19^{-}$ cells are part of the leukaemic cell clone (Hotfilder et al, 2005), this population cannot, at this stage, be satisfyingly purified, as there is always significant overlap from the $\mathrm{CD} 19^{+}$bulk leukaemic population (Vormoor et al, 1998). Till now there have been debates about whether MLL/AF4-positive leukaemia arises in a primitive pluripotent stem cell, which is expected to express the c-kit receptor CD117 (Blair \& Pamphilon, 2003) or in an immature but already lymphoid restricted progenitor/ stem cell that would be expected to be CD117 (Hotfilder et al, 2005). Due to the rarity of the $\mathrm{CD} 34^{+} \mathrm{CD} 19^{-} \mathrm{CD} 117^{+}$cell population, we have been unable to purify these cells for FISH analysis. This study revealed that the $\mathrm{CD} 34^{+} \mathrm{CD} 19^{-} \mathrm{CD} 117^{+}$cell population lacks expression of NG2, but it could not determine whether the $\mathrm{CD} 34^{+} \mathrm{CD} 19^{-} \mathrm{CD} 117^{+}$cells represent a normal haematopoietic stem cell population or a NG2negative leukaemic stem cell population.

However, in the qualitative RT-PCR, $\mathrm{CD} 34^{+} \mathrm{CD} 19^{+}$cells showed, similar to AML, higher concentrations of NG2 RNA than $\mathrm{CD} 34^{+} \mathrm{CD} 19^{-}$cells. This was confirmed by semiquantitative RT-PCR (Table I) and may indicate that, like in AML, NG2 is upregulated with lymphoid differentiation within the ALL cell clone. Yet, low levels of NG2 in ALL stem cells cannot be totally excluded at this point.

In conclusion, NG2 appears to be upregulated with increasing myeloid and probably also lymphoid differentiation within the malignant cell clone of acute leukaemic patients with MLL rearrangement. This indicates, in contrast to previous assumptions, that NG2 does not play a key role in leukaemogenesis of $M L L$-rearranged leukaemic patients, as it is not expressed within the leukaemic stem cell compartment. It has rather to be considered as an aberrant expression associated with the $M L L$ fusion oncogenes and probably lacks any biological function.

These data greatly influence the clinical relevance of NG2 expression. As NG2 is not expressed on primitive cells, it cannot be utilised as a therapeutic target against leukaemic stem cells. Moreover, its role in MRD monitoring is limited, as its expression does not allow a detection of primitive clonogenic leukaemic stem cells that possess a relapseinitiating capability.

In conclusion, our results indicate that NG2 expression is a valuable marker for the diagnosis of acute leukaemia, with $M L L$ rearrangement, but not a marker of the most relevant leukaemic stem cells. Other proteins should be tested for their capacity of detecting the leukaemia-maintaining cell. 
A

1. PCR

$+/-\quad+1+$

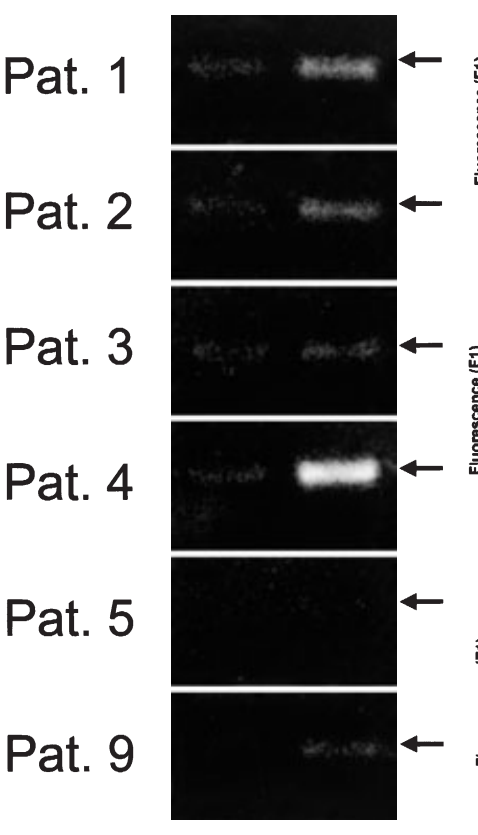

B

2. PCR
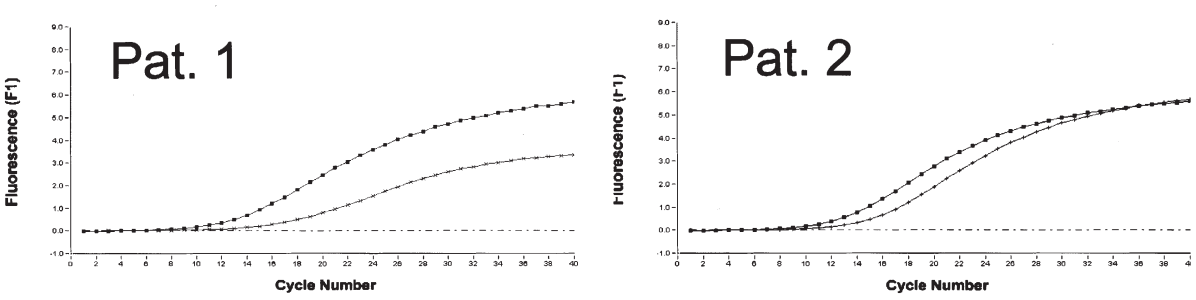

Pat. 3
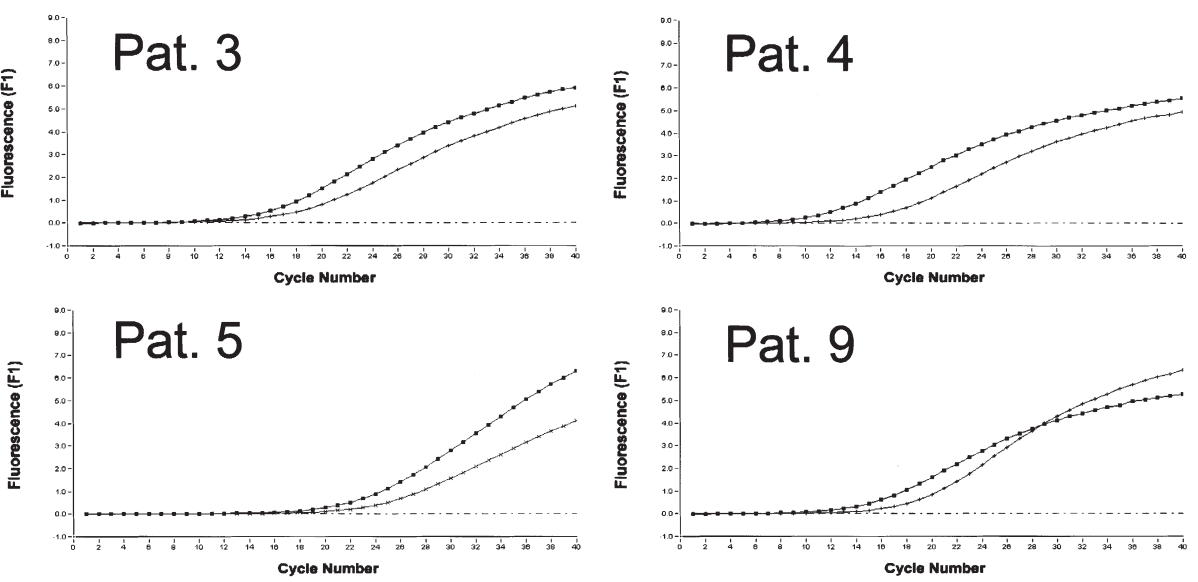

Cycle Number

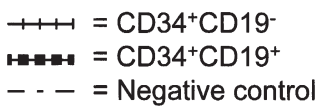

Fig 4. Reverse-transcriptase polymerase chain reaction (PCR) analysis of neuron-glial antigen $2(N G 2)$ mRNA levels in sorted CD34 ${ }^{+} \mathrm{CD} 19^{-}(+/-)$ and $\mathrm{CD} 34^{+} \mathrm{CD} 19^{+}(+/+)$cell populations in six acute lymphoblastic leukaemia patients. (A) Agarose gel electrophoresis of the qualitative, first-step PCR for NG2. Arrows indicate the expected and obtained 345-bp PCR product. (B) Crossing point analysis curves of the semiquantitative, secondstep PCR for NG2. Crossing point analysis curves obtained by HeLa dilutions are not shown.

Table I. Relative increase of the neuron-glial antigen 2 mRNA concentration within the $\mathrm{CD} 34^{+} \mathrm{CD} 19^{+}$cells compared with the $\mathrm{CD} 34^{+} \mathrm{CD} 19^{-}$cells in six acute lymphoblastic leukaemia patients.

\begin{tabular}{|c|c|c|c|c|c|}
\hline $\begin{array}{l}\text { Unique } \\
\text { patient } \\
\text { no. }\end{array}$ & $\mathrm{CD} 34^{+} \mathrm{CD} 19^{-} \mathrm{CP}$ & $\mathrm{CD}_{3} 4^{+} \mathrm{CD} 19^{-}[\mathrm{RNA}]$ & $\mathrm{CD} 34^{+} \mathrm{CD} 19^{+} \mathrm{CP}$ & $\mathrm{CD}_{3} 4^{+} \mathrm{CD} 19^{+}[\mathrm{RNA}]$ & 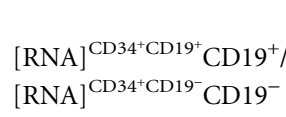 \\
\hline 1 & $9 \cdot 665$ & $0 \cdot 383$ & $8 \cdot 506$ & $0 \cdot 575$ & $1 \cdot 500$ \\
\hline 2 & $9 \cdot 268$ & $0 \cdot 441$ & 6.829 & $1 \cdot 034$ & $2 \cdot 348$ \\
\hline 3 & $10 \cdot 160$ & $0 \cdot 322$ & $8 \cdot 543$ & $0 \cdot 568$ & $1 \cdot 761$ \\
\hline 4 & $9 \cdot 615$ & 0.390 & $5 \cdot 410$ & $1 \cdot 700$ & 4.357 \\
\hline 5 & $15 \cdot 770$ & 0.045 & $14 \cdot 340$ & 0.075 & $1 \cdot 650$ \\
\hline 9 & $12 \cdot 360$ & $0 \cdot 149$ & 8.092 & 0.665 & $\begin{array}{l}4 \cdot 454 \\
\text { Mean: } 2 \cdot 678\end{array}$ \\
\hline
\end{tabular}

A semilogarithmic regression curve equation $\left([\mathrm{RNA}]=\mathrm{e}^{2 \cdot 424-0 \cdot 35 \mathrm{CP}}\right)$, generated by semiquantitative reverse-transcriptase polymerase chain reaction (RT-PCR) analysis with dilutions of HeLa cell RNA, was used to calculate the relative amount of NG2 mRNA in sorted CD34 ${ }^{+} \mathrm{CD} 19^{-}$and

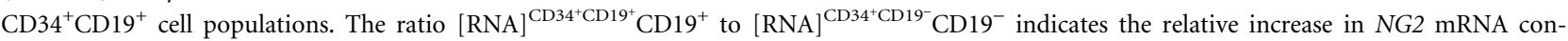
centration (CP, crossing points obtained by semiquantitative RT-PCR; [RNA], relative NG2 mRNA concentration). 


\section{Acknowledgements}

This work was supported by the Deutsche José Carreras Leukämie-Stiftung e.V. (Grant no. DJCLS R03/03). J.N. was supported by a scholarship of the Cusanuswerk.

\section{References}

Baersch, G., Baumann, M., Ritter, J., Jürgens, H. \& Vormoor, J. (1999) Expression of AC133 and CD117 on candidate normal stem cell populations in childhood B-cell precursor acute lymphoblastic leukaemia. British Journal of Haematology, 107, 572-580.

Behm, F.G., Smith, F.O., Raimondi, S.C., Pui C.-H. \& Bernstein, I.D. (1996) Human homologue of the rat chondroitin sulfate proteoglycan, NG2, detected by monoclonal antibody $7 \cdot 1$ identifies childhood acute lymphoblastic leukemias with $\mathrm{t}(4 ; 11)$ (q21;q23) or $\mathrm{t}(11 ; 19)(\mathrm{q} 23 ; \mathrm{p} 13)$ and MLL gene rearrangements. Blood, 87, 11341139.

Blair, A. \& Pamphilon, D.H. (2003) Leukaemic stem cells. Transfusion Medicine, 13, 363-375.

Blair, A., Hogge, D.E. \& Sutherland, H.J. (1998) Most acute myeloid leukemia progenitor cells with long-term proliferative ability in vitro and in vivo have the phenotype CD34+/CD71-/HLA-DR. Blood, 92, 4325-4335.

Bonnet, D. (2005) Normal and leukaemic stem cells. British Journal of Haematology, 130, 469-479.

Bonnet, D. \& Dick, J.E. (1997) Human acute myeloid leukemia is organized as a hierarchy that originates from a primitive hematopoietic cell. Nature Medicine, 3, 730-737.

Borkhardt, A., Wuchter, C., Viehmann, S., Pils, S., Teigler-Schlegel, A., Stanulla, M., Zimmermann, M., Ludwig, W.-D., Janka-Schaub, G., Schrappe, M. \& Harbott, J. (2002) Infant acute lymphoblastic leukemia - combined cytogenetic, immunophenotypical and molecular analysis of 77 cases. Leukemia, 16, 1685-1690.

Burg, M.A., Grako, K.A. \& Stallcup, W.B. (1998) Expression of the NG2 proteoglycan enhances the growth and metastatic properties of melanoma cells. Journal of Cell Physiology, 177, 299-312.

Griffin, J. \& Löwenberg, B. (1986) Clonogenic cells in acute myeloblastic leukemia. Blood, 68, 1185-1195.

Hilden, J.M., Smith, F.O., Frestedt, J.L., McGlennen, R., Howells, W.B., Sorensen, P.H.B., Arthur, D.C., Woods, W.G., Buckley, J., Bernstein, I.D. \& Kersey, J.H. (1997) MLL gene rearrangement, cytogenetic 11 q23 abnormalities, and expression of the NG2 molecule in infant acute myeloid leukemia. Blood, 89, 3801-3805.

Hotfilder, M., Röttgers, S., Rosemann, A., Jürgens, H., Harbott, J. \& Vormoor, J. (2002) Immature CD34+CD19- progenitor/stem cells in TEL/AML1-positive acute lymphoblastic leukemia are genetically and functionally normal. Blood, 100, 640-646.

Hotfilder, M., Röttgers, S., Rosemann, A., Schrauder, A., Schrappe, M., Pieters, R., Jürgens, H., Harbott, J. \& Vormoor, J. (2005) Leukemic stem cells in childhood high-risk ALL/t $(9 ; 22)$ and $\mathrm{t}(4 ; 11)$ are present in primitive lymphoid-restricted $\mathrm{CD} 34^{+} \mathrm{CD} 19^{-}$cells. Cancer $R e-$ search, 65, 1442-1449.

Lapidot, T., Sirard, C., Vormoor, J., Murdoch, B., Hoang, T., CaceresCortes, J., Minden, M., Paterson, B., Caligiuri, M. \& Dick, J. (1994) A cell initiating human acute myeloid leukaemia after transplantation into SCID mice. Nature, 367, 645-648.

Levine, J.M. \& Nishiyama, A. (1996) The NG2 chondroitin sulfate proteoglycan: a multifunctional proteoglycan associated with immature cells. Perspectives on Developmental Neurobiology, 3, 245-259.

McCulloch, E.A. (1983) Stem cells in normal and leukemic hemopoiesis (Henry Stratton Lecture). Blood, 62, 1-13.

Quijano, C.A., Moore, D., Arthur, D., Feusner, J., Winter, S.S. \& Pallavicini, M.G. (1997) Cytogenetically aberrant cells are present in the CD34+CD33-38-19- marrow compartment in children with acute lymphoblastic leukemia. Leukemia, 11, 1508-1515.

Schwartz, S., Rieder, H., Schläger, B., Burmeister, T., Fischer, L. \& Thiel, E. (2003) Expression of the human homologue of rat NG2 in adult acute lymphoblastic leukemia: close association with MLL rearrangement and a CD10-/CD24-/CD65s+/CD15+ B-cell phenotype. Leukemia, 17, 1589-1595.

Smith, F.O., Rauch, C., Williams, D.E., March, C.J., Arthur, D., Hilden, J., Lampkin, B.C., Buckley, J.D., Buckley, C.V., Woods, W.G., Dinndorf, P.A., Sorensen, P., Kersey, J., Hammond, D. \& Bernstein, I.D. (1996) The human homologue of rat NG2, a chondroitin sulfate proteoglycan, is not expressed on the cell surface of normal hematopoietic cells but is expressed by acute myeloid leukemia blasts from poor-prognosis patients with abnormalities of chromosome band 11q23. Blood, 87, 1123-1133.

Stallcup, W.B. \& Cohn, M. (1976) Correlation of surface antigens and cell type in cloned cell lines from the rat central nervous system. Experimental Cell Research, 98, 285-297.

Vormoor, J., Baersch, G., Baumann, M., Ritter, J. \& Jürgens, H. (1998) Flow cytometric identification of candidate normal stem cell populations in CD45-negative B-cell precursor acute lymphoblastic leukaemia. British Journal of Haematology, 100, 501-508.

Wuchter, C., Harbott, J., Schoch, C., Schnittger, S., Borkhardt, A., Karawajew, L., Ratei, R., Ruppert, V., Haferlach, T., Creutzig, U., Dörken, B. \& Ludwig, W-D. (2000) Detection of acute leukemia cells with mixed lineage leukemia (MLL) gene rearrangements by flow cytometry using monoclonal antibody $7 \cdot 1$. Leukemia, 14, 1232-1238. 